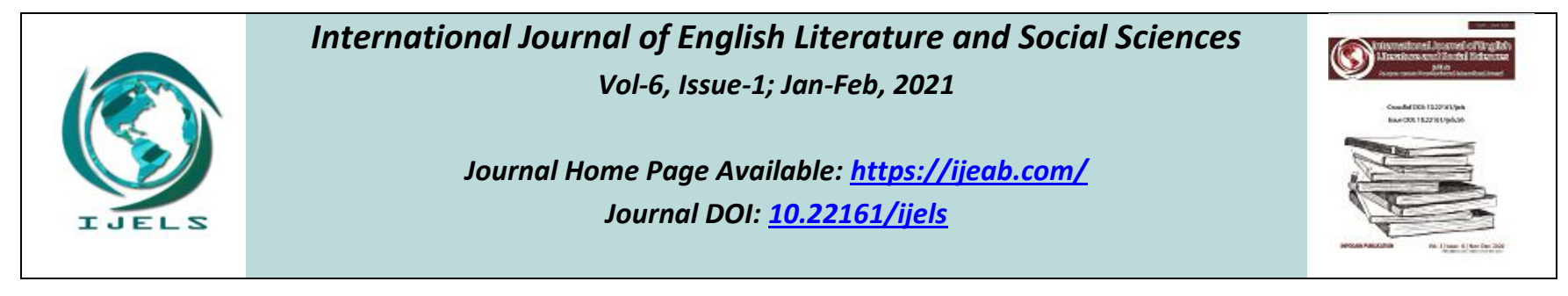

\title{
Literary Realism and Narrative Techniques in Fakir Mohan Senapati's Six Acres and a Third
}

\author{
Mrs. Anitha Merin Vincent
}

Department of English, Justice Basheer Ahmed Sayeed College for Women, Chennai, India

Received: 02 Dec 2020; Received in revised form: 11 Jan 2021; Accepted: 18 Jan 2021; Available online: 07 Feb 2021

C2021 The Author(s). Published by Infogain Publication. This is an open access article under the CC BY license (https://creativecommons.org/licenses/by/4.0/).

\begin{abstract}
Literary realism was a trend originated in the writings of French authors in the nineteenth century. Realistic novels represented contemporary society and life 'as they were'. Like naturalistic writers, they dealt with a special selection of subject matter and a special way of rendering those materials. Realistic novels held a mirror to the society revealing the most ordinary and natural of human experiences. They embraced the linear and omniscient narration to encode their narrative. This paper looks at how Senapati, a late nineteenth-century Oriya novelist, Fakir Mohan Senapathi redefines realism in his novel, Six Acres and a Third. Unlike the naturalistic mode of Mulk Raj Anand, Senapati's realism is complex rather than simply mimetic or descriptive. For him it is much more than a plain unadorned representation of the mundane written in plain language. Rather, he embodies a critical vision in its narrative style. This study also attempts to look into those features of the narrative that Senapati employs to achieve this critical vision. The modes and techniques of the narrative are closely looked at to see how the narrative unfolds various subtexts and histories.
\end{abstract}

Keywords-Carnivalesque, Decentering, Intertextuality, Narrative, Subtext.

Literary realism was a trend originated in the writings of French authors in the nineteenth century. Realistic novels represented contemporary society and life 'as they were'. They preferred the common place and the mundane, represented in minute detail. Like naturalistic writers, they dealt with a special selection of subject matter and a special way of rendering those materials. Realistic novels held a mirror to the society revealing the most ordinary and natural of human experiences. They embraced the linear and omniscient narration to encode their narrative.

This paper looks at how Senapati, a late nineteenth-century Oriya novelist, redefines realism in his novel, Six Acres and a Third. Unlike the naturalistic mode of Mulk Raj Anand, Senapati's realism is complex rather than simply mimetic or descriptive. For him it is much more than a plain unadorned representation of the mundane written in plain language. He embodies a critical vision in its narrative style. This paper attempts to look

ISSN: 2456-7620

https://dx.doi.org/10.22161/ijels.61.22 into those features of the narrative that Senapati employs to achieve this critical vision. The modes and techniques of the narrative are closely looked at to see how the narrative unfolds various subtexts and histories.

The aim of the narrative is to achieve "analytical realism", which seeks to analyze and explain social reality instead of merely holding up a mirror to it. Senapati rejects the 'marvelous or wonderful' portrayal of the Indian village, but in very plain and simple language recreates the authentic reality of Indian village life. His narrator is rooted in the rich cultural heritage of Orissa. With the help of the narrator, who employs the techniques of satire, irony, bathos, sarcasm, humor, parody, subversion and intertextuality Senapati helps his readers to generate a critical view. This paper focuses on these aspects of the narrator, who plays a critical part in helping the reader to reach at the crux of the story. 
The choice of point of view from which the story is told is arguably the most important decision that the novelist has to make, for it fundamentally affects the way readers will respond to the fictional characters and their actions (Lodge 26). Therefore, integral to our understanding of the text is to know Senapati's narrator: his identity and function. Satya $\mathrm{P}$ Mohanty in his introduction to the text characterizes the narrator as a "touter-narrator". The touter in the Oriya culture is the "disreputable wit who inhabits the lower rungs of the society and is always a bit unreliable" (Senapati 6). By using his wit and intelligence to disguise his motives, this touter-narrator acts as an effective social and cultural actor. The narrator is unnamed and has little vestige of an individual identity, but seems to be close to the powerful and acts like one of their henchmen. However, by his casual and colloquial tone he strikes a close relationship with the characters as well as the readers of the novel. We also see the narrator as distanced from the readers both by time and space. This leads us to the question of the reliability of the narrator and the extent to which the readers can trust his narrative. Finding answers to these questions would take us to the modes of narratives the narrator employs in the novel.

Unlike the narrators we see in the texts of the contemporaries of Senapati, in Six Acres and a Third we meet a narrator who is new to the English as well as Indian literary conventions, one who breaks the barriers of time and space and converses directly to the reader. A reliable narrator poses as though he understands the plot well. This makes the reader trust the narrator. An unreliable omniscient narrator, according to David Lodge, could occur only in a "very deviant, experimental text" (Lodge 154). The narrator of Six Acres and a Third is self reflexive and unreliable. He is conscious of his role as a narrator and comments on his narration, making the readers aware of his presence and his action of narrating the story.

The narrator is constantly conversing with the reader. The narrator addresses the reader directly as "brother" or "dear reader", thus striking a rapport with the reader. He constantly makes the reader aware that he/she is reading just a novel. The reader is not permitted to identify with the story or the characters. He is pulled out of the world of the fiction and is constantly reminded of his position as that of a reader: outside the world of fiction. In very much the same way as Brecht's Epic theatre, which every now and then interrupts the action and makes the actors comment on it, the postmodern narrator interrupts the flow of the narration in order to encourage his audience to criticize and oppose, rather than passively accept the social conditions and the modes of behavior the characters represent.

Using the unreliable narrator is the technique Senapati employs to enable the reader develop a critical distance from the text. Once the reader identifies the tactic of the narrator he could foreground the significance of the subtexts. Let us look at the nature of the narrator. Could he be trusted completely like the traditional omniscient narrator? The unreliable narrator is a man of contradictions. He promises the reader that "the details herein presented are accurate and precise; you may read on with your eyes closed" (Senapati 68). Later he contradicts himself saying "You see it is not good to rely on the opinion of others. You must try to use your wits to draw your own conclusions" (Senapati 90). Such comments of the narrator, according to Linda Hutcheon, constitute a typical example of the "rupturing effect" in fiction, an effect which consists of the narrative agency revealing itself. The rupturing effect could be seen as "the simultaneous inscribing and subverting of the conventions of the narrative" (Hutcheon 49).

According to David Lodge "even a characternarrator cannot be a hundred percent unreliable. If everything he or she says is palpably false, that only tells us what we already know, namely that the novel is a work of fiction" (Lodge 154). Thus we see that though our narrator is unreliable, he is not completely untruthful. For instance, about Mangaraj the narrator says, "In reality, Mangaraj mistreated everyone: he would win their trust and then drag them into the law courts to steal their land" (Senapati 53). Later we learn how apt this judgement of the narrator is.

The narrator himself raises an argument and drives the attention of the reader to it by hand, promising that he would explain it to him. But suddenly deserts him at it, leaving him to arrive at a conclusion himself. An unreliable narrator can deceive the readers by misreporting the events. He wins the confidence of the reader only to break it. "Dear reader, if we report everything... it will tire you out", but he always tires his readers by his numerous digressions (Senapati 51). Most often he gives only instances and hints and hopes that "for intelligent people hints usually suffice" (Senapati 68). An ordinary reader who fails to read between the lines might miss out the point the narrator wants to foreground. But at the same time the narrator is not an untrained, amateur one that the reader hardly misses the point.

The narrator is a self conscious narrator. The narrator as he himself reveals, employs "the main technique of getting at a matter through inference" (Senapati 90). He declares to his readers the technique he 
has employed. Thus we see that his digressions are not accidental but suggestive and deliberate. Even when he says that it will be against his nature "to record irrelevant thing" he is conscious of the instances where he digresses and acknowledges it. "Our pen moves helter-skelter, but our main story never loses its way: it is always on course..." (Senapati 112). However, he does not get back into the main plot right away, instead goes on with his digressions, which is clear by the fact that the core of the story - the Bhagia and Saria episode - is related to the reader only in the tenth chapter.

Once we understand the narrator we see that these digressions are deliberate. For, he assumes that "intelligent readers will be able to draw their own conclusions" (Senapati 43) and that hints usually suffice them (Senapati 69). The digressions and the allusions create a "rich metaphorical subtext." The duty of the narrator is not just to narrate the story of Mangaraj but to throw light upon the radical social vision that the novel upholds. Hidden behind the lengthy digressions are the subtexts which are meant to be analysed critically by a detached reader. The techniques the narrator employs are directed to the achievement of this end.

Senapati offers a novel which is not structured by linear narrative. Though the novel seems to have a linear mode of narration, the lengthy digressions that the narrator make does not escape the reader. The plot of Six Acres and a Third revolves around Mangaraj's attempt to appropriate a village weaver's verdant small holding, the six and a third acres of land. But we see how scattered the main thread of the plot is. Apart from Mangaraj other major characters appear only very late. Champa, though is introduced in chapter one by a passing reference, is described in detail only in chapter 6. It is only in chapter 10 the owners of the eponymous chunk of land is introduced. There are chapters like "The Asura Pond" whose presence or absence might not cater to the whole of the novel.

The narrator is a self-conscious satirist, social agent and a social critic and a moral philosopher. He takes upon himself the role of agency. The narrator is not trying to hide the harsh realities of village life from the reader, but by his sharp but ironic sarcasm and humour he is making known the hidden truths. He employs this technique to let the readers think critically and bring forth a change. According to Jennifer Harford Vargas, the narrator maintains an ironic and parodic distance from the Eurocentric ways of interpreting the reality. Such a distance helps the narrator to deconstruct the hierarchies of power, knowledge and class privilege.
It should also be noted that there is no 'centre' in the novel. Even though the novel tells us the story of Mangaraj an intelligent reader could see that he is not at the center of the novel. The novel, especially the narrative techniques, could be seen as 'dialogic' incorporating many different styles or voices, which as it were talk to each other and to other voices outside the text; the discourses of culture and society at large (Lodge 128). What the story is about is not significant but how it is told becomes significant. The medium itself becomes the message. As Linda Hutcheon says the centre no longer holds. And from this decentred perspective, the marginal takes on new significance. The novel, through its rich subtext provides a strong voice to the marginalised.

History has always recorded the voices of the elites. Unlike the elite historiography the novel exposes a "carnivalesque" of voices, a concept introduced by Bakhtin. It unfolds the layers of stories untold and unheard. Senapati's use of "we" and "our" gives the book a common acceptance. The novel introduces a mingling of voices from diverse social levels. But it is also interesting to note that the narrator stands as the spokesperson both the rich and the poor. He is an impartial narrator who equally satirizes and comments on the follies of both the upper class and the lower class. He freely mocks at and subverts authority: religious (comments on the Brahmins as well as the baniyas), social (on the landlords as well as the peasants) as well as literary (subverts the classic Sanskrit and ancient texts). Senapati employs stylistic strategies of irony, satire, intertextuality and defamiliarization as the basis for its critical realism.

Throughout the narrative we see the presence of subtle but biting satire and irony. The novel pokes fun at the new babus and the new western style of living they hold on to, forgetting one's own culture and tradition (Senapati 69, 84). Irony is the key feature of the narrator's discourse. The meaning narrator implies differs sharply from the meaning that is apparent. In A Rhetoric of Irony, Wayne Booth identifies as stable irony that in which the speaker or author makes available to the reader an assertion or position which, whether explicit or implied, serves as a firm ground for ironically qualifying or subverting the surface meaning (Booth 147). "The irony of the narrator can be subtle, but it often swells to full-blown sarcasm, at times evoking an irreverent and explosive form of humour" (Senapati 4).

The tone of the narrator is that of a village gossip monger. The narrative abounds in sarcasm and irony. The touter narrator converses with the readers through his wit and humour. But beneath this tone of lighthearted humour is embodied a critical tone which reminds the reader of the purpose of the narrative. 
Senapati's uses satire as a weapon to laugh at the landlords, castes, the religious institutions, the colonial regime etc. His aim is to laugh people out of their follies. Senapati's narrative does not exclude any of the faults of his contemporary society from the harsh satire. He mocks at the new babu's who, after acquiring the English education considers themselves alien to their own culture and tradition. "Ask a new babu his grandfather's father's name and he will hem and haw, but the names of the ancestors of the England's Charles the third would readily roll off his tongue"'(Senapati 84).

The religious institutions and caste and class divisions are also mocked at in the novel. His passing reference in chapter one throws light upon one of the situations which force the people to take up religious conversions. The Brahmins as well as the weavers is subjected to his scrutiny. He does not leave alone the land lords or the weavers. His aim is not just humour, but change. By pointing the follies of the people he calls for a change. He invites the readers to reflect and meditate to bring forth a change. By using the technique of bathos Senapati evokes laughter in his reader. He brings together the trivial and the sublime together often evoking pearls of laughter, thereby igniting the thought process of the reader.

The use of striking metaphors and animal imagery are one of the features of the narrative. In the novel we see recurrent imagery of the prey and the predator- the kaduakhampi birds and the kingfishers stand for the colonized and the colonizers respectively. Champa is described as "a wily, wicked she-jackal", Saria, as a simple innocent ewe. The bleating billy goat, slaughtered at the durbar of Dildar Mian was predicting the predicament of Dildar Mian at the hands of Mangaraj.

In Six Acres And A Third Senapati has employed a self-conscious form of intertextuality. Intertextuality has been a much used term since its first introduction by Julia Kristeva. As Graham Allen says in his book Intertextuality, "the fundamental concept of intertextuality is that no text, much as it might like to appear so, is original and unique in itself; rather it is a tissue of inevitable, and to an extent unwitting, references to and quotations from other texts" (Allen 5). Senapati credits his audience with the necessary experience to make sense of such allusions, quotations etc, his deliberate employment of the technique of subversion, to ignite the critical faculty of the reader.

Intertextuality is entwined in the roots of $\underline{\mathrm{Six}}$ Acres and a Third. The narrator tend to exploit this postmodern technique, "freely recycling earlier works of literature to shape or add resonance to, their presentation of contemporary life" (Lodge 99). Theorists have identifies many ways by which by which one text can refer to another. Parody, pastiche, direct quotation, structural parallelism are a few. Most of these could be identified in Six Acres and a Third. The text is filled with allusions, direct quotations and parody. The narrator borrows quotes from Sanskrit texts like the Sastras and Nyaya Sastra, Chanakyaniti (Senapati 53), Kalidasa's works like Raghuvamsha, Meghadutum, from texts written in Oriya such as Oriya Bhagavata, Guru Gita etc. Apart from these written old texts he also makes apt use of sayings both in Sanskrit and Oriya. This technique of intertextuality that the narrator employs could be seen as an 'alienatory mode' which runs counter to the dominant realist tradition which focuses on persuading the audience to believe in the narrative. It appeals to the critical detachment rather than of emotional involvement.

It is in the intertextuality of the text that the narrator employs the postmodern techniques of parody and pastiche. Postmodern texts are "parodic in their intertextual relation" to the traditional, conventional means of narratology says Linda Hutcheon. Several texts come together in one text. The narrator purposefully mistranslates and parodies the slokas and quotes from the ancient texts not just to evoke laughter in the reader but his ultimate aim is one of enlightening the audience. Instead of preaching the reader reciting the scripture he tends to take a different route entirely. He enlightens the reader by entertaining him.

Use of allusions is an instance of intertextuality. The novel is filled with allusions, metaphors and digressions. A careful scrutiny of the rhetorics in the novel reveals strategically placed allusions to the labouring poor, labour and theft of the fruit of the labour by the rich and the powerful. The allusions and digressions create a "rich metaphorical subtext" (Senapati 9). The subtexts explore a variety of topics ranging from the socio-economic impacts of the British land laws to the cultural crisis due creation of a new generation of English educated middle class Oriya Babus, from various divisions within the society based on caste to the economic structuring of the village religious practices, from the hegemonic imposition of English on an Oriya speaking society to the corruption involved in the judicial and the law and order systems of the state.

Senapati calls for active participation of his reader to decode the signs the narrator highlights to explore the subtexts that are beneath the layers of digressions and allusions. We have seen that the reader is also an active participant in the plot. He is treated as an insider and is encouraged to be a part of the story. But at the same time he is kept at a distance and the technique employed by the narrator helps the readers to maintain a critical distance. 
By leaving gaps in the narrative the narrator makes it possible for the readers of all the times to fill in the gap according his knowledge and assumptions. There by concretize the meaning.

According to Barthes, it is the reader's decoding which makes sense of all the factors that narratives bring into play. Thus the reader's response is critical to the understanding of the novel. Six Acres and a Third could be seen as an open ended novel, a postmodern trend. Though the narrator ties up the two ends of the main plot by the death of Mangaraj, we see that the story does not end there. The subtexts remain open for the interpretation of the reader. It is the reader who should provide a meaning to the text. The contemporary reader could come to the conclusion that though the days of imperialism and feudalism is over, the days of oppression still continue. Situations have not changed. The modern readers could place the story in the modern context and see that nothing has changed.

The sole aim of the "analytical realism" of the narrative is to guide the readers to understand the analytical and truth telling function of the discourse. The narrative helps the reader to arrive at the realization that a change is desirable and it is the duty of the readers as social beings to be aware of the social situations for his own well being and that of his fellow beings. Senapati has succeeded in conveying the message to his readers without distorting it. The techniques of irony, satire, intertextuality, humour, parody, subversion have helped the readers to identify the rich subtexts of the novel and made possible an understanding of the micro structures of social worlds they depict. Analyzing the modes of narrative Senapati employs, we agree with Satya P Mohanty's that "what makes six acres and a third unusual is its critical vision embodied in its narrative style or mode, in the complex way the novel is narrated and organized as a literary text" (Senapati 2).

\section{REFERENCES}

[1] Allen, Graham. Intertextuality. New York. Routledge, 2000.Print.

[2] Anjaria, Ulka. "Satire, Literary Realism and The Indian State: Six Acres And A Third And Raag Darbari." EPW 41.46 (2006): 4795-4800. Print.

[3] Barry, peter. Beginning theory: an introduction of literary and cultural theory. Delhi: Viva books, 2008. Print.

[4] Booth, Wayne. The Rhetoric of Fiction. Penguin Books, 1991. Print.

[5] Drolet, Michael, ed. The Post Modernism Reader. London: Routledge, 2004. Print.

[6] Fludernik, Monika. An Introduction To Narratology. London: Routledge, 2006. Print.
[7] Horan, Claire. "Representation Of Women And Gender Relations In Six Acres And A Third”. EPW 41.46 (2006): 4789-4794. Print.

[8] Hutcheon, Linda. A Poetics Of Postmodernism: History, Theory, Fiction. London: Routledge, 1988. Print.

[9] Lodge, David. Art of fiction. Vikings: Penguin, 1994. Print.

[10] Mohapatra, Himansu. S. "Two Classic Tales Of Village India”. $E P W$ 43.50. (2008): 62-69. Print.

[11] Paul, Cobley. Narrative. London: Routledge, 2001. Print.

[12] Senapati, Fakir Mohan. Six Acres and a Third. New Delhi: Penguin, 2006. Print.

[13] Vargas, Jennifer Harford. "A Tale Of Two Novels From The Global South”. EPW 43.50 (2008): 52-61. Print. 